\title{
African Swine Fever (ASF): Threat of Excintion to Nias Local Pig Farm
}

\author{
Jonathan Anugrah Lase ${ }^{1 *}$, Novita Ardiarini ${ }^{1}$, Dian Lestari ${ }^{2}$, Verika Armnasyah Mendrofa ${ }^{3}$, \\ and Anggella Tesalonika Tombuku ${ }^{4}$ \\ ${ }^{1}$ North Maluku Assesment Institute for Agricultural Techology, Ministry of Agriculture, Indonesia \\ ${ }^{2}$ Department Nutrition and Animal Feed Technology, Faculty of Agriculture and Animal Husbandry, \\ Muhammadiyah Kotabumi University \\ ${ }^{3}$ Department of Animal Production Science and Tecnhology, Faculty of Animal Science, IPB \\ University \\ ${ }^{4}$ North Sulawesi Assesment Institute for Agricultural Techology, Ministry of Agriculture, Indonesia
}

\begin{abstract}
African Swine Fever (ASF) is a disease that infects pigs. Common symptoms caused by ASF attacks on pigs are bleeding in the feces and ears as well as sudden weakness of livestock, unable to stand, and death of livestock. ASF virus is not zoonotic so it does not affect human health. This virus has entered Indonesian territory, including the Nias Island, where most of the people cultivate local pigs. The ASF outbreak on local pigs in Nias resulted in the death of many pigs. This paper discusses the spread and death of local pigs due to ASF attacks in Nias. Data compiled from the field and the Animal Husbandry Office in 2020 in the Nias islands, it is known that the pigs that died due to the ASF outbreak reached 120,592 a pigs. Meanwhile, the fact found are that the handling of infected pigs cannot be done optimally, because until now, effective treatment and vaccination for the treatment and prevention of ASF infection has not been found. Therefore, in order to prevent the spread of the plague from becoming more widespread, the current methods that can be applied are the application of biosecurity in the cattle sheds, isolation of infected livestock and the role of the government in regulating the entry and exit route for pigs in the Nias region.
\end{abstract}

Keywords: ASF virus, Infection, Local pig, Nias island

\section{Introduction}

In the last one year, pig farms in many parts of Indonesia have experienced an outbreak of African Swine Fever (ASF). this plague infection resulted in the death of pigs on a large number. In Indonesia, areas where many people cultivate pigs are greatly affected by the ASF outbreak. There have been many reports in several regions in Indonesia experiencing ASF attacks on pigs. ASF has entered the East Nusa Tenggara (NTT) region because it is directly adjacent to Timor Leste, an area that has been infected with ASF [1]. Several regions in Indonesia are experiencing ASF infection, which has resulted in a high number of pig deaths. In mainland North Sumatra, 40,000 pigs have died in traditional farms [2]. ASF's entry route to Indonesia is wide open due to traffic from the territory of an ASF-infected country entering Indonesian territory. In general, the clinical symptoms of ASF resemble

\footnotetext{
* Corresponding author: jhonlase2810@ gmail.com
} 
fever; bleeding in the stool and ear opening; livestock suddenly weak; can't stand up; and this was followed by the rapid death of livestock. African Swine Fever (ASF) has been declared an emergency disease affecting pigs since 2007 [3]. ASF was started in 1900 in East Africa resulting in the sudden death of pigs in the region. ASF began to spread in 2007, attacking pigs in Eastern Europe [4]. ASF is transmitted through the bite of a tick (Ornithodorus sp) and does not infect humans (zoonosis) but has an economic impact on pig farmers due to its high morbidity and mortality [5].

African Swine Fever (ASF) is a highly contagious disease and can cause sudden and rapid death in pigs. ASF was first identified from East Africa in 1921, until December 2019 it was suspected that the ASF virus had entered Indonesia. ASF incidents in Indonesia are officially announced through the Decree of the Minister of Agriculture Number 820/KPTS/PK.320/M/12/2019 concerning Statement of African Swine Fever Outbreak in Several Districts in North Sumatra Province. Livestock that are sensitive to this virus are pigs, so this virus is often known as swine fever. The ASF virus is caused by a doublestranded DNA virus from the Asfivirus genus of the Asfarviridae family, and has 23 ASFV genotypes [4]. ASF has similarities with Hog Cholera, which previously infected pigs in many regions, and often cannot even be distinguished between the two. The general symptoms of the ASF virus are high temperature and loss of appetite, but in some cases symptoms such as vomiting, diarrhea, crowded, and unable to stand [6]. The ASF virus in pigs is highly contagious and can cause various bleeding in internal organs so that the mortality rate is high [7].

ASF virus is very resistant to environmental influences, and stable at $\mathrm{pH} 4-13$, and can survive in blood $\left(4^{\circ} \mathrm{C}\right)$ during 18 months, in cold meat during 15 weeks, in frozen meat for several years, in ham during 6 months and in in a cage during 1 month [8]. Based on this explanation, it shows that the ASF virus can survive in the environment and is also resistant to disinfectants. The ASF virus can spread to livestock by direct or indirect contact. Direct contact is characterized by physical contact between infected livestock and healthy animals, while indirect contact can be through equipment, feed and drinks contaminated with the virus. In Indonesia African Swine Fever (ASF) is known as African swine fever. There are many reports about ASF which causes the death of pigs in several regions in Indonesia. The regions in Indonesia that are attacked by ASF are areas whose people generally raise pigs, these regions are East Nusa Tenggara (NTT), Bali, Kalimantan, North Sumatra and the Nias islands. It was reported that the region was facing a fairly severe ASF outbreak. Nias is one of the regions where most of the people are engaged in pig farming. In the Nias island, it was reported that throughout 2020 there were a large number of pig deaths.

\section{Methods}

This research was conducted using descriptive analysis. The data were obtained from the Department of Agriculture and Animal Husbandry in 4 districts and 1 municipality in 2020. The data was tabulated, then a descriptive analysis was carried out. The data obtained is the number of pig deaths in 2 periods, in June and December 2020.

\section{Result and Discussion}

\subsection{ASF attacks in Nias Island}

Nias island, which consists of 4 regional districts and 1 municipality. In all regions of the Nias islands, pigs are the largest population when compared to other livestock populations, this is because most of the people pigs farming. The pig breed that is widely cultivated among 
Nias traditional breeders is the local pig breed. Nias local pig is one of Indonesia's local pig germplasm. As one of the pig germplasm Nias Nias is unique both in terms of its morphology, waste utilization and adaptability. In 2019 the total population of pigs in Nias reached 495.35 with meat production of $33,088,244 \mathrm{~kg}$ [9]. This means that pigs have an important role in the joints of community life in the Nias Islands.

In general, pig farming in Nias is still carried out in a traditional, semi-intensive manner with minimal feeding and tends to pay less attention to housing biosecurity. This traditional pattern of pigs farming has resulted in relatively low livestock production. The existence of local Nias pigs as germplasm is under threat due to the attack of the African Swine fever (ASF) outbreak which resulted in the death of pigs in a very high number throughout the Nias Islands. Data on pig mortality in the Nias Islands region were successfully compiled from the Agriculture and Animal Husbandry Department Office in each administrative region in Nias. The data is shown in Figure 1.

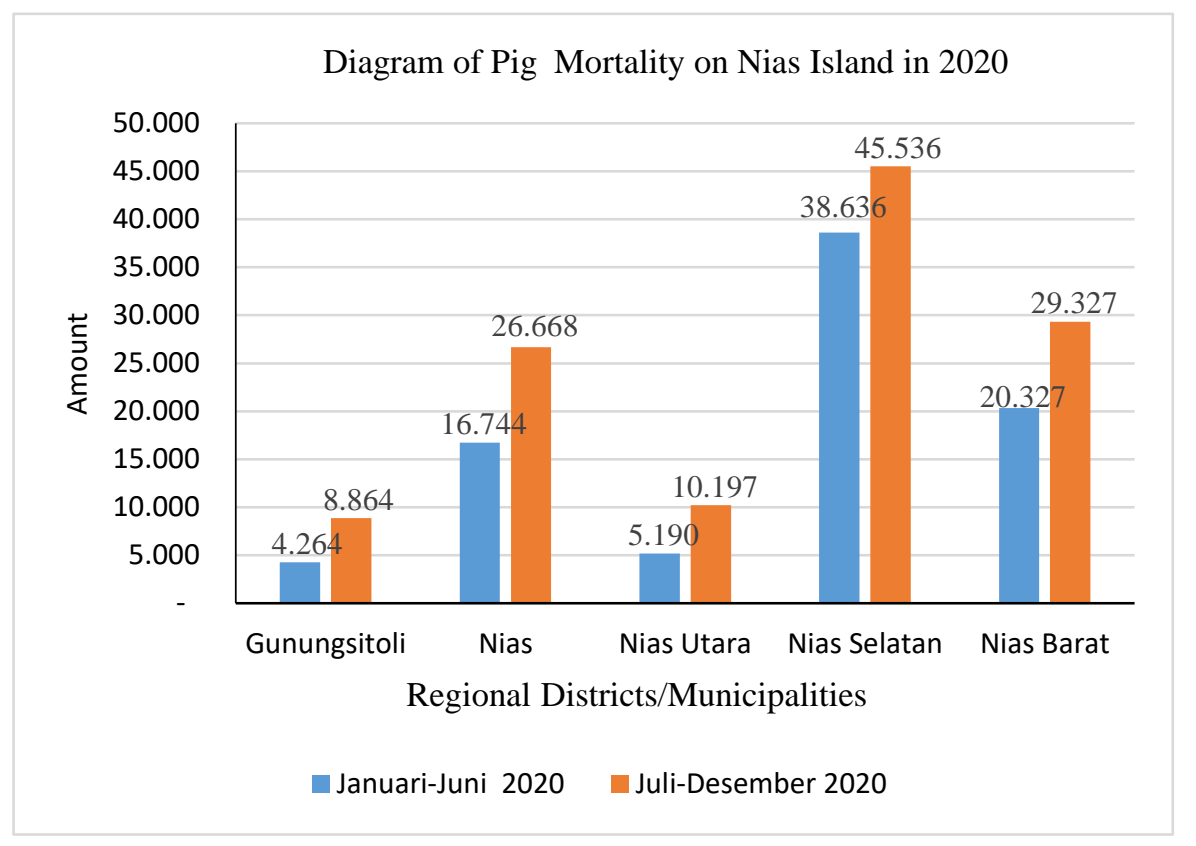

Fig. 1. The mortality rate of pigs due to the ASF outbreak in Nias Islands in 2020

According to the data in Figure 1, it can be seen that the ASF attack in Nias resulted in the death of 120,592 a pigs. From the data displayed, it is known that the death of pigs continues to increase from June to December 2020. Of the 5 (five) administrative regions in the Nias Islands, South Nias Regency is the region that recorded the highest pig mortality in 2020 , amounting to 45,536 a pigs. Subsequent pig deaths were recorded in West Nias District, followed by Nias, North Nias and Gunungsitoli districts, respectively 29,327, $26,668,10,197$ and 8,864 a pigs. The impact of the ASF attack has resulted in very high pig mortality in the Nias region. As a result of this outbreak, it affected the economy of the people in the Nias Islands, due to the livelihoods of most of the people as pig breeders [9]. The impact of ASF affects many aspects of life in Nias people. Apart from the economic side, it also affects the cultural life of the Nias people. This is because pigs are one of the commodities that have an important role in meeting the needs of meat, and the rituals of traditional Nias community ceremonial [10]. In the life order of the people of Nias, pig farming is a priority because it has an important role in various aspects of community life. 
Dead pigs in all regions of Nias showed symptoms similar to those of ASF which were reported in mainland North Sumatra. The Animal Husbandry Service Office of North Sumatra Province in September 2019 reported that 40,000 pigs had died on people's farms. Symptoms that are shown by cattle before death are fever, lack of appetite, limp cattle and subsequently the pigs die. The process of entering ASF in the Indonesian territory, including the Sumatra mainland and the Nias region, is estimated to have similarities with the spread in the African and European regions. It is known that the spread in Europe is mainly through trucks transporting pigs, swill feeding by aircraft and ships [11]. The ASF entry route in the territory of Indonesia is likely through swill feeding from aircraft originating from infected countries as well as from non-consumable passenger luggage that has been contaminated by ASF which is then used by breeders as pig feed [2].

Observations from the field in the Nias region, show that the use of swill feeding among traditional Nias breeders is still widely practiced because the cost is relatively cheap, although it is inefficient and does not have a significant impact on livestock productivity. A case that is often found in the field is that farmers often provide swill feeding without processing (heating the food) first [2]. Furthermore, apart from swill feeding that has been contaminated with ASF and used as animal feed, another route for ASF entry to Indonesia is through formites, equipment items such as shoes that have been infected and have had contact with ASF infected pigs [2].

\subsection{Prevention of transmission measures ASF in Nias Island}

From many literatures, it is known that there has not been found an effective treatment and vaccine against ASF. Effective treatment and prevention measures for ASF through vaccination were not yet available [2]. There are several vaccines being developed, one of which is an inactivated vaccine that produces an antibody response in livestock, but it is not yet protective enough [12]. Therefore, preventing transmission from one region to another is a concrete step that can be taken. The high number of pig mortality cases in the Nias region can be categorized as emerging disease, so it needs attention from all parties. Governments, communities, breeders, traders must take serious precautions to reduce ASF infection. Concrete steps that can be taken to prevent this disease from becoming more widespread in the Nias region are prevention of disease through the application of biosecurites, waste treatment, isolation of infected livestock and regulation of traffic in and out of livestock and livestock products in the Nias island region.

\subsection{Overview ASF in the world}

ASF was first reported in Kenya in the 1920s, and is known as an acute bloody disease that attacks local pigs (Sus scrofa domesticus) in that country. As a result of this epidemic, local pigs in Kenya were destroyed by 100 percent [13]. The ASF outbreak is thought to be due to pigs being infected with wild animals, namely wild boars. The source of infection was carried by wild boars [14]. It is predicted that ASF has existed for a long time in the countries of the sub-Sabhara part of South Africa. The initial distribution of ASF was predicted via the Central and West African route across the islands of the Indian Ocean, Madagascar in 1981 [15] via Mauritius in 2007 [16]. The distribution and transmission cycle of ASF in the African region was caused by having a high pig population, traditional (extensive) farming patterns and the use of swill feeding as pig feed [17]. The reported spread of ASF outside of Africa was via Portugal in 1957, through waste on airlines which was processed and used as hog feed [13].

In Europe, ASF then spread to Spain in the mid-1990s. In Spain, scientific identification was carried out and it is known that this virus carrier is caused by the bite of the soft tick 
Ornthodoros erraticus [5]. Furthermore, in Europe the carriers of Ornithodoros sp were identified, including the Ornithodoros porcinus, Ornithodoros moubata, Ornithodoros domesticus and Ornithodoros porcinus groups. Ornithodoros porcinus was identified as a vector and reservoir for ASF virus in Africa and then ASF spread rapidly in other European countries. According to Plowright et al. [18] countries that become ASF distribution routes in Europe are, Malta (1978), Italy (1967), France (1964, 1967, 1977), Belgium (1985) and the Netherlands (1986). Further, transcontinental spread of ASF was reported with the entry of ASF into Georgia wi the Kaukasus region. The delay in identifying and controlling ASF in Europe made the spread of ASF unstoppable and in a short time it spread to neighboring countries, including Armenia, Azerbaijan and several regions in Russia. Especially in Russia, it is reported to have occurred in the region of Cheznya, Oseatia Utar-Alania, Ingushetia Orenburbg, Krasnodarskiy and extending to Ukraine [16].

In the Asian region, the first reported incidence of ASF was in China (August 2018) [19]. The entry of ASF to Chinese territory was identified through the transportation route of aircraft and food transport trucks contaminated with the ASF virus, the traffic of pigs, and pork products contaminated with the ASF virus [20]. China, which is known as the largest pork producer in the world, has experienced an ASF attack, and since the ASF attack on pig farms in China, it has easily spread to surrounding countries. The distribution starts from Mongolia (2019), Hong Kong, to North Korea, South Korea, (2019), Laos (2019), Myanmar (2019), the Philippines, Timor-Leste, New Guinea, India and Indonesia [20]. The very fast spread of ASF from China to surrounding countries in the Asian region is also the same as the case that occurred in Africa, is due to the density of domestic pig populations, loose application of biosecurity, provision of animal feed from aircraft food waste that has been contaminated with ASF [21], trade in pigs in traditional markets, the spread of the virus in slaughterhouses with poor sanitation [22].

The results of the study indicate that in several regions in China, ASF has been present in the habitat of wild pigs for approximately 5 years previously [23]. Wild boars in China are suspected of carrying ASF to local pigs because wild boars have a close interaction with the activities of residents in the region [24]. African Swine Fever (ASF) was declared an epidemic of world re-emerging diseases in 2007 [3] because of its very rapid spread and mortality in pigs. The massive spread of ASF in the Asian region is caused by poorly controlled supply chains, trade and livestock traffic.

\section{Conclusion}

African Swine Fever (ASF) is an epidemic currently attacking pig farms in many regions in Indonesia. The impact of this ASF attack resulted in the death of pigs in a very high number. Common symptoms caused by ASF attacks on pigs are bleeding in the feces and ears, suddenly weakened livestock, unable to stand, and death of the cattle. In the Nias Islands region throughout 2020, 120,592 a pigs were recorded as having died due to ASF. The ASF attack caused economic losses to the Nias community, who mostly raised pigs. Until now, there has not been found an effective treatment and vaccination for ASF control. Measures to prevent the spread of ASF from becoming more widespread are strict biosecurity, isolation of infected livestock, processing livestock waste, and strict regulation of the traffic in and out of livestock and livestock products in the Nias region.

\section{References}

1. A. Winarso, N. Hartanto, S. Rofi'ah, Ancaman African Swine Fever masuk ke wilayah Indonesia melalui Nusa Tenggara Timur, dalam Prosiding Seminar Nasional VII 
Fakultas Kedokteran Hewan Universitas Nusa Cendana. 17 Oct 2019, Kupang, Indonesia (2019)

2. I. Sendow, A. Ratnawati, N.L.P.I Dharmayanti, M. Saepulloh, Wartazoa 30, 15 (2020)

3. Cappai, Stefano, R. Sandro, C. Annamaria, L. Alberto, R. Federica, Prev. Veterinary Med. 152, 1 (2018)

4. P. J. Sánchez-Cordón, M. Montoya, A. L. Reis, L. K. Dixon, Veterinary J. 233, 41 (2018)

5. F. S. Boinas, A. J. Wilson, G. H. Hutchings, C. Martins, L. J. Dixon, PLoS ONE. 6, e20383 (2011)

6. OIE, The World Organization for Animal Health, 27 (2019)

7. W. B. Giarda, Y. L. Nugrahini, Potensi daging babi Bali untuk membantu menyokong kembali perekonomian Indonesia, dalam Prosiding Seminar Nasional dalam Rangka Dies Natalis ke-44 UNS. 22 Juli 2020, Surakarta, Indonesia (2020)

8. T. W. Retnaningsih, mengenal demam babi afrika atau african swine fever (ASF) (Medik Veteriner Muda, Dinas Peternakan dan Kesehatan Hewan Provinsi Jawa Tengah, 2019)

9. Badan Pusat Statistik (BPS) Sumatera Utara, (Provinsi Sumatera Utara dalam angka, Populasi Ternak Menurut Kabupaten/Kota dan Jenis ternak di Provinsi Sumatera Utara, 498 (2020)

10. T. Telaumbanua, J. Sunderman 1, 1 (2019)

11. I. Mur, B. Martinez-Lopez, J. M. Sanchez-Vizcaino, BMC Vet. Res. 8, 1 (2012)

12. I. Titov, G. Burmakina, Y. Morgunov, S. Morgunov, A. Koltsov, A. Malogolovkin, D. Kolbasov, Arch Virol 162, 3081 (2017)

13. S. Costard, B. Wieland, W. de Glanville, F. Jori, R. Rowlands, W. Vosloo, F. Roger, D. U. Pfeiffer, L. K. Dixon, Phil. Trans. R. Soc. B, 364, (2009)

14. E. Montgomery, J Compar Path Therapeu, 24, (1921)

15. F. Roger, Ratovonjato, P. Vola, G. Uilenberg, Exp. and Applied Acarology, 25, 263 (2001)

16. OIE, Organizacion Internacional de Epizootias, in African Swine Fever, (2009)

17. M. L. Penrith, W. Vosloo, F. Jori, A. D. Basto, Virus Res, 173, 228 (2013)

18. W. Plowright, G. R. Thomson, J. A. Neser, (Oxford University Press, UK, 1994)

19. D. Zhao, R. Liu, X. Zhang, F. Li, J. Wang, J. Zhang, X. Liu, L. Wang, J. Zhang, X. Wu, Y. Guan, W. Chen, X. Wang, X. He, Z. Bu, Em. Microbes \& Infec 8, 438 (2019)

20. FAO, Food and Agriculture Organization of the United Nations. African Swine Fever threatens people's Republic of China, in a rapid risk assessment of ASF introduction (2018) [Internet]: [accessed Februari 2021]

21. T. Vergne, C. Chen-Fu, S. Li, J. Cappelle, J. Edwards, V. Martin, Vet. Rec, 181 (2017)

22. L. K. Dixon, K. Stahl, F. Jori, L. Vial, D. U. Pfeiffer. Annu. Rev. Anim Biosci, 8, 221 (2020)

23. K. Śmietanka, G. Woźniakowski, E. Kozak, K. Niemczuk, M. Frączyk, Ł. Bocian, Emerg. Infect Dis, 22, 1201 (2016)

24. Q. Liu, K. Yan, Y. Lu, M. Li, Y. Yan. J. of Mount. Sci, 16 (2019) 